\title{
Urgensi Perubahan Kebijakan untuk Penegakkan Independensi Media di Indonesia
}

\author{
Darmanto \\ Balai Pengkajian dan Pengembangan Komunikasi dan Informatika (BPPKI), \\ Balitbang SDM Kementerian Komunikasi dan Informatika
}

\section{ABSTRAK}

Independensi media massa di Indonesia terutama dalam memberitakan isu-isu politik kekuasaan seperti Pemilihan Umum, telah menimbulkan kekhawatiran banyak pihak karena dirasakan dapat mengancam kehidupan demokrasi. Hasil penelitian sejumlah Iembaga mengenai kinerja pemberitaan media massa cetak dan elektronik pada waktu menjelang, saat berlangsungnya, dan pasca Pemilihan Umum Legislatif serta Pemilihan Presiden dan Wakil Presiden 2014 menunjukkan adanya kecenderungan sebagian besar media tidak independen. Akibatnya, media terbelah menjadi dua kekuatan yang saling berhadap-hadapan dan pada akhirnya keterbelahan itu merembet ke masyarakat. Akan tetapi, upaya untuk menegakkan independensi media di Indonesia ternyata tidak mudah karena ada banyak faktor penghambat. Salah satu faktor penghambat yang besar pengaruhnya ialah produk kebijakan yang ada masih sangat lemah. Sehubungan dengan itu perlu adanya perubahan kebijakan yang dapat mendorong terwujudnya penegakkan independensi media di Indonesia.

Kata kunci: kebijakan publik, demokrasi, independensi, jurnalisme, media penyiaran

\footnotetext{
P<smiles>[Te]</smiles>
}

Edmund Burke menyebut media massa sebagai pilar keempat (fourth estate) demokrasi serta memiliki kedudukan yang sejajar dengan Tuhan (Lord), Gereja (Church), maupun Majelis Rendah (Commons). Pendapat tersebut didasarkan pada kekuatan yang dimiliki oleh media massa dalam hal m'enyampaikan informasi sehingga media ddpat meningkatkan publisitas atau bahkan justru menahannya. Media massa mampu melakukan kontrol terhadap pemerintah dan majelis atas dasar prinsip kebebasan untuk menghasilkan informasi yang dapat menjamin pelaksanaan demokrasi dan memajukan masyarakat. Oleh karena itulah kebebasan pers merupakan hal yang esensial untuk menjamin eksistensi media sebagai pilar keempat demokrasi. Hakekat dari kebebasan pers pada dasarnya ialah keleluasaan bagi individu untuk menyampaikan pendapat tanpa adanya sensor, serta kemampuan media untuk melakukan kontrol terhadap pemerintah maupun kekuatan lain (McQuaill, 2011: 185-187).

Kebebasan dari segala bentuk larangan dan tekanan pihak luar dalam menentukan arah kebijakan redaksional itulah yang kemudian dikenal dengan istilah kebebasan pers atau independensi media. Bagi media massa, independensi merupakan roh yang menghidupinya. Kerja media tidak sekedar persoalan teknis menyajikan berita, tetapi di 
dalamnya mengandung ideologi memberikan informasi untuk pemberdayaan masyarakat. Untuk itu, media harus menegakkan independensi dan netralitas (Siregar, 2013). Dalam perspektif teori normatif, media massa harus bebas dari kontrol pemerintah yang berlebihan dan dari kelompok kepentingan tertentu agar independen dalam memberitakan fakta sosial dan memenuhi kebutuhan khalayak (Karman, 2014: 70-71). Sebab, langkah penting dalam pengejaran kebenaran dan memberi informasi kepada warga bukanlah netralitas, melainkan independensi (Kovach dan Rosenstiel, 2006: 122). Kovach dan Rosentiel menegaskan bahwa esensi independensi media adalah kepindahan dari kepatuhan kepada partai politik kepada kepentingan publik (Ibid. h. 125).

Selama era pemerintahan Orde Baru (1966-1998) dengan sistem politiknya yang otoriter, media massa dihegemoni oleh negara dan hanya menjadi alat pembenar bagi rezim dalam memertahankan kekuasaan (Gayatri, 2006: 59). Pada masa itu media massa benar-benar dikontrol oleh negara melalui mekanisme perizinan sehingga kepemilikan bisa saja di tangan swasta, tetapi eksistensinya ditentukan oleh negara yang sewaktu-waktu dapat mencabut izin usaha maupun izin penerbitan (D'Haens, Gazali, dan Verest, 2000: 169-171). Dalam sistem demokrasi, media massa memiliki kemerdekaan sehingga dapat bersikap netral, independen, dan jika didukung profesionalisme dapat menjadi kekuatan kontrol sosial (Gayatri, loc.cit.).

Walaupun secara teoretis sistem politik yang dianut Indonesia saat ini sudah demokratis, tetapi praktik penyelenggaraan media massa saat ini masih jauh dari kondisi ideal dan dapat mengancam kelangsungan sistem demokrasi yang telah kita pilih. Fakta empirik menunjukkan bahwa demokrasi dan kemerdekaan pers tidak dapat dipisahkan. Era reformasi yang berlangsung sejak 1998 dan semula diharapkan dapat menjadi momentum terwujudnya kemerdekaan pers, ternyata pada akhirnya berjalan secara terseokseok. Pers memang benar-benar terbebas dari hegemoni negara sehingga siapa pun dapat menerbitkan surat kabar dan atau majalah dengan prosedur perizinan yang sederhana asalkan mempunyai cukup modal. Demikian pula, untuk media penyiaran walau pun sampai kini tetap ada kontrol yang ketat dari negara atas dasar pertimbangan teknis teknologi maupun pertimbangan lain seperti kepentingan negara, ekonomi dan politik (McQuaill, 2011: 38), tetapi pada dasarnya kemerdekaan pers sudah terwujud di Indonesia.

Meskipun secara etimologi istilah "kemerdekaan" dan "independensi" berasal dari kata yang sama, yaitu independence (Bahasa Inggris), tetapi pengaruh diksinya menjadi sangat berbeda. Istilah "kemerdekaan pers" pada umumnya dikaitkan dengan ada atau tidak adanya intervensi dari negara atau kekuatan lain di luar media. Ketidakmerdekaan pers selahu dibayangkan berhubungan dengan kekuatan negara yang sifatnya sistemik, politis, dan hegemonik. Dengan kata lain, diksi dari istilah "kemerdekaan pers" lebih mengarah pada upaya pemertahanan diri dari intervensi negara, sedangkan istilah "independensi" lebih banyak digunakan untuk melakukan identifikasi mengenai arah kebijakan redaksional suatu media massa dalam memberitakan kasus tertentu.

Dalam artikel ini, konsep independensi yang dipakai sepenuhnya merujuk pada pengertian yang ada dalam KEJ. Pada bagian penafsiran Pasal I KEJ disebutkan bahwa independen berarti memberitakan peristiwa atau fakta 
sesuai dengan suara hati nurani tanpa campur tangan, paksaan, dan intervensi dari pihak lain termasuk pemilik perusahaan pers. Dengan kata lain, independensi ialah kemampuan media untuk bersikap bebas berdasarkan suara hati nurani dalam merespon persoalan yang muncul di masyarakat untuk kemudian dimanisfestasikan ke dalam produk jurnalistik yang bebas dari intervensi pihak mana pun. Independensi pada umumnya sangat ditentukan oleh profesionalisme jurnalis dari media yang bersangkutan. Semakin tinggi profesionalisme jurnalis, besar kemungkinan tingkat independensi media yang dikelolanya juga tinggi.

Walaupun pers - termasuk di dalamnya media penyiara - akhirnya terbebas dari tekanan negara, tetapi tidak otomatis melahirkan independensi. Sebab, seperti yang disinyalir oleh Amir Efendi Siregar, yang terjadi hanyalah perpindahan kontrol. Pada era Orde Baru, kóntrol terhadap media sepenuhnya ada di tangan pemerintah beralih, tetapi pada era reformasi kontrol tersebut berpindah ke tangan pemodal melalui pasar bebas dan kemudian melahirkan otoritarianisme kápital (Siregar, 2012:7).

Melihat realitas seperti itu, maka dipandang mendesak perlu adanya kebijakan yang dapat mendorong terwujudnya penegakan independensi media di Indonesia. Bertitik tolak dari latar belakang tersebut, maka fokus permasalahan yang akan dibahas dalam artikel ini ialah kebijakan seperti apa yang diperlukan untuk dapat menegakkan independensi media di Indonesia mengingat kebijakan yang ada sekarang ternyata tidak mampu memecahkan permasalahan yang dihadapi masyarakat mengenai independensi media. Adapun tujuan yang hendak dicapai melalui studi ini ialah teridentifikasinya persoalanpersoalan kebijakan yang menghambat terwujudnya independensi media di
Indonesia dan kemudian menemutunjukkan solusi yang dapat ditawarkan untuk mengatasi masalah tersebut.

\section{Potret Independensi}

Dalam satu dasa warsa terakhir, isu independensi media (massa) di Indonesia menjadi perhatian serius dan telah menimbulkan kekhawatiran di berbagai pihak, baik kalangan akademisi, pekerja media, pengamat, bahkan sampai dengan kalangan politisi dan anggota masyarakat pada umumnya. Kekhawatiran itu didasarkan pada keyakinan bahwa sistem demokrasi akan dapat hidup subur jika ditopang oleh media massa yang profesional dan independen. Dengan kata lain, jika media massa makin terkooptasi oleh kepentingan kelompok tertentu seperti pebisnis dan penguasa, hal itu dapat menjadi ancaman bagi kehidupan demokrasi.

Munculnya kekhawatiran mengenai masa depan media di Indonesia, terutama dipicu oleh penggunaan media massa oleh pemiliknya yang menjadi politisi dan atau sebagai pengurus Partai Politik (Parpol) untuk kepentingan kampanye diri maupun parpolnya. Sentimen itu kemudian diperkuat oleh keterbelahan media massa pada saat Pemilu Presiden tahun 2014. Pada masa menjelang, saat, dan pasca Pemilu Presiden 2014 mediamedia besar terbelah menjadi dua kubu antara yang mendukung pasangan Calon Presiden dan Wakil Presiden Prabowo Subianto dengan Hatta Rajasa (PrabowoHatta) dan pasangan Joko Widodo dengan Jusuf Kalla (Jokowi-JK). Media-media di bawah naungan MNC Grup milik Hary Tanoesoedibjo seperti RCTI, MNC, Global $T V$, dan Koran Sindo serta media massa di bawah kemilikan Bakrie Grup seperti TV One dan ANTV secara terang-terangan mendukung Pasangan Prabowo-Hatta, sedangkan media-media yang berada di bawah kepemilikan Ketua Umum Partai 
Nasdem Surya Paloh seperti Metro TV dan Media Indonesia mendukung pasangan Calon Presiden Jokowi-JK. Koran Tempo dan Jakarta Post meskipun secara terangterangan menyatakan dukungannya terhadap pasangan Capres/Cawapres Jokowi-JK, tidak berarti menjadi bagian dari permasalahan independensi.

Dewan Pers telah mengantisipasi adanya ketidakindependenan media massa pada Pemilu 2014. Oleh karena itu pada tahun 2013, Dewan Pers melibatkan tiga Lembaga Swadaya Masyarakat (LSM) di bidang media, yaitu Remotivi (Jakarta), PR2Media (Yogyakarta), dan Masyarakat Peduli Media (MPM) Yogyakarta untuk melakukan riset. Hasilnya tidak berbeda dengan hipotesis yang diyakini sebelumnya bahwa media massa yang dimiliki oleh pengurus parpol menunjukkan kecenderungan tidak independen dalam produk jurnalisme mereka.

Hasil penelitian yang dilakukan oleh MPM pada tahun 2013 atau saat menjelang pelaksanaan Pemilu 2014 dengan menggunakan metode analisis isi terhadap tiga stasiun televisi: Trans $T V$, Metro TV, dan TV One serta dua surat kabar: Rakyat Merdeka dan Media Indonesia mendapati kenyataan bahwa ada problem independensi dalam media massa di Indonesia, terutama yang dimiliki oleh pengurus parpol. Trans TV dan Rakyat Merdeka yang tidak berafiliasi pada parpol tertentu dalam pemberitaannya cenderung netral, sedangkan media yang dimiliki oleh tokoh politik memperlihatkan diri tidak independen. Metro TV dan Media Indonesia yang dimiliki oleh Surya Paloh dalam pemberitaannya lebih menonjolkan figur sang pemilik dan partai Nasdem yang dipimpinnya. Adapun $T V$ One selama menjelang pelaksanaan Pemilu 2014 menjadi instrumen bagi Abu Rizal Bakri (ARB) untuk mempopulerkan diri dan partai Golkar yang dipimpinnya karena ARB memiliki agenda untuk mencalonkan diri sebagai Presiden pada
Pemilu 2014. (Masduki,dkk, 2013: 49-52 dan Tim MPM, 2014: hal. 81-82).

Kecenderungan yang sama diperlihatkan oleh hasil penelitian PR2Media (Pemantau Regulasi dan Regulator Media) kerja sama dengan Dewan Pers tahun 2013. Pada waktu itu, PR2Media meneliti 372 item berita dari Kompas.com, akezone.com. surat kabar Kompas, Koran Sindo, dan media televisi RCTI. Temuannya, berita-berita di okezone.com, koran Sindo dan RCTI milik Hary Tanoesoedibjo (HT) yang pada waktu itu menjadi petinggi partai Hanura dan memproklamasikan diri bakal menjadi Calon Wakil Presiden mendampingi Wiranto, lebih banyak menampilkan sosok pemiliknya. Hal itu berbeda dengan kecenderungan beritaberita di kompas.com dan koran Kompas yang pemiliknya (Jakob Oetama) bukan orang parpol (Siregar, dkk, 2014: 11-14).

Temuan yang tidak jauh berbeda dapat dilihat dari hasil penelitian Remotivi tahun 2013 yang memperlihatkan bahwa stasiun televisi RCTI memberikan porsi waktu cukup banyak bagi kemunculan HT selaku pemilik RCTI sebagai subyek berita. Frekuensi kemunculan HT yang cukup tinggi di RCTI ternyata tidak diikuti kemunculannya di media lain di luar grup MNC. Hal itu berarti bahwa faktor yang menjadikan HT sering muncul di RCTI lebih disebabkan oleh posisinya sebagai pemilik, bukan karena dia sebagai sumber berita yang potensial. (Heychael dan Dhona, 2014: 101). Demikian pula hasil riset yang dilakukan tahun 2014 terhadap 11 stasiun televisi menunjukkan kecenderungan yang sama, yakni adanya keperpihakan sesuai dengan afiliasi politik dari pemilik stasiun penyiaran yang bersangkutan (Heychael, 2014: 4-5)

Pada tahun 2014, MPM kembali melakukan penelitian isi media terkait dengan pemberitaan Pemilu Legislatif dan Pemilu Presiden. Metode yang digunakan adalah analisis isi (content analysis) dan analisis pembingkaian (framing) terhadap lima surat kabar, yaitu Jawa Pos, Koran Sindo, Media Indonesia, Jurnal Nasional (saat ini sudah tidak terbit), dan Kedaulatan Rakyat. Dari lima surat kabar yang diteliti hanya Jawa Pos yang 
pemiliknya bukan pengurus parpol, tetapi Dahlan Iskan sang pemilik sempat mengikuti konvensi Calon Presiden yang diselenggarakan oleh Partai Demokrat. Hasil penelitian dengan menggunakan analisis isi menunjukkan kenyataan bahwa terdapat kecenderungan pada lima surat kabar yang diteliti untuk menonjolkan pemilik atau parpol di mana sang pemilik media berafiliasi. Temuan ini konsisten dengan hasil penelitian terhadap lima surat kabar yang sama, tetapi menggunakan metode analisis pembingkaian (Wicaksono, at.al, 2015: 146-149).

Selain sumber-sumber yang telah disebutkan di atas, cukup banyak kajian mengenai independensi media massa di Indonesia seperti dilakukan oleh Widiyanto (2009), Andrias dan Satori (2014), Wahyudin, maupun oleh Herawati dan Yasin (2014). Hasil kajian ketiganya menunjukkan kecenderungan yang sama bahwa kepentingan kapital dan politik menjadi kekuatan yang pada akhirnya menekan pekerja media untuk tunduk pada kemauan sang pemilik media. Oleh karena itu patut diperhatikan seruan Ketua Dewan Pers Bagir Manan bahwa ketika terjadi kolaborasi antara perusahaan pers dengan penguasa akan dapat mengancam kemerdekaan dan independensi media (Manan, 2012: 126129).

Berdasarkan paparan tersebut, dapat disimpulkan bahwa independensi media massa di Indonesia saat ini secara umum masih tergolong rendah dan memrihatinkan. Memang beberapa media masih menunjukkan kinerja yang baik dalam menjaga independensi, tetapi proporsinya jauh di bawah jumlah media yang tidak independen sehingga gambaran umumnya jauh dari ideal. Kondisi seperti ini tentu merupakan pergumulan tersendiri mengingat usia era reformasi sudah lewat dari dua windu, tetapi independensi media yang dicitacitakan sejak masa Orde Baru sepertinya justru semakin jauh dari harapan.

\section{Kinerja Kebijakan}

Mengingat kajian mengenai faktorfaktor yang menghambat terwujudnya independensi media di Indonesia telah banyak dilakukan, maka studi ini berusaha mengkaji dari sisi lain, yakni aspek kinerja kebijakan. Adapun yang dimaksud dengan kinerja kebijakan (policy performance) ialah derajat di mana hasil kebijakan yang ada memberikan kontribusi terhadap pencapaian nilai-nilai atau terpecahkannya masalah yang dihadapi (Dunn, 2003: 109). Dalam konteks ini nilai yang dimaksud adalah terwujudnya independensi media massa, terutama media penyiaran, di Indonesia. Sejauh mana kebijakan publik yang ada mampu mewujudkan penegakkan indenpendensi media penyiaran seperti yang diharapkan banyak pihak.

Istilah kebijakan publik yang dipakai di sini mengacu pada konsep sebagaimana berlaku dalam studi kebijakan publik pada umumnya. Menurut Thomas R. Dye dalam Wibawa (2011: 2), kebijakan publik ialah apa pun yang dipilih oleh pemerintah untuk dilakukan atau tidak dilakukan. Hal itu berarti, jika pemerintah entah karena alasan lalai maupun dengan sengaja tidak melakukan sesuatu ketika muncul suatu persoalan untuk dipecahkan, berarti itulah wujud kebijakan yang diambilnya. Pendapat lain mengatakan bahwa kebijakan publik adalah semua keputusan politik yang diambil oleh lembaga publik, yaitu lembaga yang sumber pendanaannya berasal dari publik dengan berbagai mekanisme penarikannya. Adapun Kebijakan publik dapat dipilah menjadi empat kategori, yaitu: (1) kebijakan yang sifatnya formal, (2) konvensi, (3) ucapan pejabat, dan (4) perilaku pejabat. Kebijakan yang bersifat formal diwujudkan dalam bentuk tertulis dan terdiri dari tiga jenis, yaitu: (1) hukum 
(pidana, perdata, agama, khusus), (2) perundang-undangan (UU, PP, Perda), dan (3) regulasi (PP, Perpres, Permen, Perda). (Nugroho, 2013: 8-24).

Bertitik tolak dari pengertian tentang kebijakan publik tersebut, dapat dijelaskan bahwa bentuk kebijakan publik yang telah dibuat oleh negara (tidak terbatas pada eksekutif) untuk mengatur media massa di Indonesia sebenarnya sudah cukup banyak. Kebijakan publik dalam bentuk undang-undang yang secara khusus mengatur mengenai media massa ada dua, yaitu UU No. 40 Tahun 1999 tentang Pers, dan UU Nomor 32 Tahun 2002 tentang Penyiaran. Kemudian pada tingkat Peraturan Pemerintah (PP) ada 7 produk, yaitu PP No. 11, 12, 13, 49, 50, 51, dan 52 yang semuanya diterbitkan tahun 2005 dan merupakan turunan dari UU Penyiaran tahun 2002.

Dari PP tersebut kemudian lahir banyak turunan regulasi yang dibuat oleh Kementerian Komunikasi dan Informatika, Komisi Penyiaran Indonesia (KPI), maupun Peraturan Daerah (Perda). Regulasi yang dibuat di tingkat Kementerian Kominfo pada umumnya terkait dengan Izin Penyelenggaraan Penyiaran (IPP) dan penggunaan frekuensi, sedangkan regulasi yang dibuat oleh KPI pada umumnya mengenai isi siaran. Selain itu, sebagaimana diamanatkan oleh UU Penyiaran, KPI juga menyusun Pedoman Perilaku Penyiaran dan Standar Program Siaran (P3SPS). Kemudian Perda yang dibuat oleh Pemerintah Kabupaten/Kota maupun Peraturan Bupati/Walikota yang terkait dengan penyiaran, semuanya mengenai Lembaga Penyiaran Publik Lokal (LPPL).

Regulasi (aturan pelaksanaan) lain yang terkait dengan tata penyelenggaraan media massa dibuat oleh Dewan Pers yang kedudukannya sebagai lembaga independen bentukan dari UU No.40/1999 tentang Pers. Salah satu produk regulasi Dewan Pers yang sangat ialah Surat Keputusan Dewan Pers No.03/SK-DP/III/2006 tanggal 24 Maret 2006 yang kemudian disahkan sebagai Peraturan Dewan Pers Nomor 6/Peraturan-DP/V/2008tentang Kode Etik Jurnalistik (KEJ) yang sifatnya mengikat bagi semua jurnalis di Indonesia.

Dari berbagai bentuk kebijakan publik mengenai media massa, khususnya penyiaran, isu independensi ternyata tidak mendapatkan perhatian memadai sehingga tidak dapat menjadi instrumen untuk menegakkan independensi media. Dalam Undang-undang Nomor 40 Tahun 1999 tentang Pers tidak ditemukan ketentuan mengenai indepedensi. Adapun dalam Undang-undang Nomor 32 Tahun 2002 tentang Penyiaran, kata "independen" muncul ketika mengatur mengenai keberadaan Komisi Penyiaran Indonesia (Pasal 7 ayat 2) yang berarti tidak secara langsung mengatur mengenai independensi siaran. Kata "independen" kembali muncul ketika mengatur tentang keberadaan Lembaga Penyiaran Publik (Pasal 14 ayat 1) dan Lembaga Penyiaran Komunitas (Pasal 21 ayat 1), sedangkan pada pasal-pasal yang mengatur mengenai Lembaga Penyiaran Swasta tidak terdapat ketentuan mengenai "independensi".

Di tingkat PP, Peraturan Menteri (Komunikasi dan Informatika) dan Perda penyiaran, pengaturan mengenai independensi tidak juga ditemukan. Pengaturan yang ada dalam PP hanya mengenai netralitas. Padahal, netralitas dan independensi merupakan dua konsep yang sangat berbeda. Netral yang berarti tidak memihak, belum tentu mencerminkan independensi. Netralitas media relatif lebih mudah diwujudkan dibandingkan dengan independensi.

Pengaturan mengenai independensi baru kita temukan dalam aturan pelaksana yang lebih rendah tingkatannya. Terkait dengan UU No. 40/1999, istilah independensi kita 
temukan pada KEJ Pasal 1 yang berbunyi: "Wartawan Indonesia bersikap independen, menghasilkan berita yang akurat, berimbang, dan tidak beritikad buruk". Kemudian pada bagian penafsitan dijelaskan bahwa yang dimaksud dengan "independen berarti memberitakan peristiwa atau fakta sesuai dengan suara hati nurani tanpa campur tangan, paksaan, dan intervensi dari pihak lain termasuk pemilik perusahaan pers". Jadi menurut KEJ dan penafsirannya, esensi dari independensi media ialah memberitakan suatu peristiwa atau fakta sesuai dengan suara hati nurani jurnalis, tanpa adanya campur tangan, paksaan, dan intervensi dari pihak lain termasuk pemilik perusahaan pers. Oleh karena itu media yang independen bisa saja memihak sejauh keperpihakan itu diambil berdasarkan suara hati nurani jurnalis dan bukan oleh karena adanya intervensi dari luar maupun tekanan pemilik media. Dalam konteks Pemilu Presiden RI tahun 2014, surat kabar The Jakarta Post dan media cetak Tempo terang-terangan memperlihatkan keperpihakannya kepada pasangan Jokowi JK. Hal itu tidak dapat dikatakan sebagai tidak independen jika pengambilan keputusan itu murni pilihan jurnalis yang didasarkan pada suara hati nurani semata.

Istilah independensi kembali muncul dalam KEJ terkait dengan penafsiran atas Pasal 6 yang bebunyi,"Wartawan Indonesia tidak menyalahgunakan profesi dan tidak menerima suap". Dalam penafsiran butir (b) dikatakan bahwa suap adalah segala pemberian dalam bentuk uang, benda atau fasilitas dari pihak lain yang mempengaruhi independensi (cetak miring oleh penulis).

Adapun ketentuan mengenai independensi dalam regulasi penyiaran terdapat pada Peraturan KPI No. o1/P/KPI/03/2012 tentang Pedoman Perilaku Penyiaran $\left(\mathrm{P}_{3}\right)$. Pada bab VII terkait dengan perlindungan kepentingan publik, Pasal 11 ayat (2) menyebutkan bahwa Lembaga penyiaran wajib menjaga independensi dan netralitas isi siaran dalam setiap program siaran. Kemudian pada bab XVIII mengenai prinsip-prinsip jurnalistik, Pasal 22 ayat (1) berbunyi:

"Lembaga penyiaran wajib menjalankan dan menjunjung tinggi idealisme jurnalistik yang menyajikan informasi untuk kepentingan publik dan pemberdayaan masyarakat, membangun dan menegakkan demokrasi, mencari kebenaran, melakukan koreksi dan kontrol sosial, dan bersikap independen".

Selanjutnya pada ayat (5) pengaturan mengenai indepedensi kembali kita temukan ketentuannya sebagai berikut:

"Lembaga penyiaran wajib menjaga independensi dalam proses produksi program siaran jurnalistik untuk tidak dipengaruhi oleh pihak eksternal maupun internal termasuk pemodal atau pemilik lembaga penyiaran".

(tanda bold dibuat oleh penulis)

Bagaimana dengan isi Peraturan KPI No. 02/P/KPI/03/2012 tentang Standar Program Siaran (SPS)? Dalam peraturan yang seluruhnya terdiri dari 94 pasal itu, ternyata tidak ditemukan kata independensi. Tidak adanya pengaturan mengenai independensi dalam SPS bisa saja dimaknai bahwa para pembuat kebijakan di bidang penyiaran belum menganggap urgen masalah tersebut. Padahal kenyataannya, isu independensi merupakan permasalahan krusial yang terjadi dalam media penyiaran Indonesia sekarang ini. Sebagian besar media penyiaran, terutama televisi swasta, telah 
terperangkap dalam praktik ketidakindependenan. Media penyiaran televisi yang dimiliki petinggi partai, dengan tidak maluomalunya telah mencengkeram jurnalisnya sehingga menjadi tidak independen.

Meskipun Pedoman Perilaku Penyiaran mewajibkan lembaga penyiaran untuk menjaga dan bersikap independen, tetapi kebijakan itu sebenarnya mandul karena tidak ada ketentuan sanksi bagi yang melanggar. Dalam Bab XXX Pasal 50 disebutkan bahwa ketentuan mengenai sanksi administratif atas pelanggaran $\mathrm{P}_{3}$ diatur dalam Peraturan KPI tentang SPS. Akan tetapi, setelah dilakukan penelusuran pada bagian sanksi dan penanggungjawab (Bab XXX, Pasal 75 78) dan bagian sanksi administrasi (Bab XXXI, Pasal 79) ternyata tidak ada ketentuan sanksi bagi yang melanggar Pasal 22 ayat (1) dan ayat (5). Jadi wajar kalau praktik-praktik penyiaran yang tidak independen terus saja terjadi karena memang tidak ada sanksi bagi pihak yang melanggar.

Berdasarkan uraian tersebut, jelas bahwa kinerja kebijakan publik terkait dengan penegakkan independensi media masih sangat rendah dan memprihatinkan. Sejauh ini belum terlihat adanya komitmen dari negara (sekali lagi tidak terbatas eksekutif) yang tercermin dalam bentuk kebijakan untuk menegakkan independensi media. Rendahnya kinerja kebijakan tersebut mengakibatkan, sebesar apa pun energi yang dikeluarkan untuk mengritisi praktik-praktik tidak independensinya media, tentu tidak akan membawa pengaruh besar atau tidak efektif. Kebijakan yang ada sekarang ini ternyata tidak mampu memecahkan masalah yang dihadapi masyarakat ketika menghadapi praktik-praktik penyiaran yang tidak independen.

\section{Pexubahan Kebijakan}

Melihat kenyataan bahwa kebijakan yang ada sekarang tidak efektif karena terbukti tidak mampu memecahkan permasalahan yang dihadapi masyarakat terkait dengan independensi media, maka perlu adanya perubahan kebijakan. Menurut Anderson dalam Winarno (2014: 250-252) terdapat tiga bentuk perubahan kebijakan. Pertama, kebijakan yang bersifat inkremental atau dalam terminologi Jawa lebih dikenal dengan istilah tambal sulam, yaitu menyempurnakan kebijakan yang sudah ada dengan cara menambahi hal-hal yang kurang dan memperbaiki bagian-bagian yang tidak relevan lagi. Kedua, membuat undang-undang baru untuk mengatur halhal yang sifatnya khusus. Ketiga, perubahan secara besar-besaran karena adanya pergantian rezim, biasanya dilangsungkan pascapemilu.

Mengacu pada konsep perubahan kebijakan yang dikemukakan Anderson dan melihat perkembangan lingkungan kebijakan yang ada, maka perubahan kebijakan yang dapat diusulkan ada dua. Pertama, terkait dengan keberadaan media massa cetak yang diatur melalui UU Pers, perubahan dapat dilakukan dalam bentuk inkremental. Negara dapat melakukan perubahan kebijakan dengan melakukan penambahan pasal yang mengatur tentang independensi media. Adapun terkait dengan media penyiaran perubahan kebijakan dapat dilakukan dengan memilih bentuk kedua, yaitu dengan membuat undang-undang baru. Usulan ini disampaikan mengingat DPR RI telah menempatkan RUU Penyiaran sebagai prioritas Prolegnas 2015 yang berarti akan adanya pembentukan undang-undang baru tentang penyiaran untuk menggantikan undang-undang yang ada. Dengan demikian momentum ini harus dimanfaatkan sebaik-baiknya oleh masyarakat sipil, kelompok-kelompok 
penekan dan semua pihak yang berkepentingan untuk memperjuangkan terwujudnya independensi melalui perjuangan politis di Senayan.

\section{Penutup}

Menurunnya tingkat independensi media seperti yang akhir-akhir ini dirasakan oleh berbagai pihak merupakan fenomena yang perlu mendapatkan perhatian serius, sebab kalau kondisi demikian dibiarkan berlangsung terus, tentu akan membahayakan kehidupan demokrasi yang telah menjadi pilihan bangsa Indonesia. Melemahnya independensi tersebut terjadi akibat kuatnya cengkeraman kapital yang berkolaborasi dengan penguasa serta cerdik dalam memanfaatkan celah-celah kebijakan yang memungkinkan mereka bermain untuk mendapatkan keuntungan.

Mengingat lemahnya regulasi yang ada, maka upaya untuk menegakkan independensi media harus dilakukan melalui perubahan kebijakan. Bentuk perubahan kebijakan yang ada dapat dibedakan antara media cetak dengan media penyiaran. Untuk mendukung terwujudnya independensi media cetak, perubahan dapat dilakukan secara inkremental, yakni menambahkan pasalpasal baru yang sesuai pada peraturan perundangan yang sudah ada. Meskipun proses untuk ini tetap melibatkan DPR RI, tetapi karena sifatnya hanya mengubah beberapa bagian tentu tidak akan menguras energi yang banyak. Adapun untuk mendukung terwujudnya independensi media penyiaran, perubahan harus dilakukan dengan membentuk undang-undang baru yang kini memperoleh momentun dengan ditetapkannya RUU Penyiaran sebagai program priorits Prolegnas (Program Legislasi Nasional) 2015 oleh DPR RI. Terkait dengan hal tersebut, tentu dibutuhkan sinergitas dari berbagai pihak untuk dapat memanfaatkan momentum pembahasan RUU Penyiaran sebagai pintu masuk untuk memperjuangkan pengaturan mengenai independensi media. 


\section{Daftar Pustaka:}

Andrias, Mohammad Ali, Ahmad Satori. (2014). Kepentingan Politik dan Hegemoni Pemilik Media Massa. Jurnal Observasi Vol. 12 No.2, hal. 101-112, ISSN:1412-5900, Bandung: BPPKI

D'Hanens, Leen; Effendi Gazali, dan Chantal Verest. (2000). Pembuat Berita TV Memandang Lahan serta Racikan Mereka di Masa Jaya dan Berlalunya Rezim Soeharto. Dalam Dedy N. Hidayat, Effendi Gazali, Harsono Suwardi, dan Ishadi SK. "Pers dalam "Revolusi Mei" Runtuhnya sebuah Hegemoni. Jakarta: Gramedia

Dunn, William N. (2005). Pengantar Analisis Kebijakan Publik (terjemahan: Samodra Wibawa, at.al) edisi Kedua. Yogyakarta: Gadjah Mada University Press.

Gayatri, Gati. (2006). Membangun Format Kemitraan Media dalam Rangka Diseminasi Informasi. Jurnal Studi Komunikasi dan Media 10 (1), Januari-Juni. ISSN 1410-6051

Heychael, Muhamad dan Holy Rafika Dhona, 2014. " Independensi Televisi Menjelang Pemilu 2014: Ketika Media Jadi Corong Kepentingan Politik Pemilik," dalam Jurnal Dewan Pers Edisi No. 09, Juli, hal. 89-121. Jakarta: Dewan Pers. ISSN: 2085-6199.

Heychael, Muhamad. (2014), Independensi Televisi Menjelang Pemilu Presiden 2014 : Ketika Media Jadi Corong Kepentingan Politik Pemilik (Bag. 2). Jakarta: Remotivi (Laporan Penelitian)

Karman. (2014). Monopoli Kepemilikan Media dan Lenyaplah Hak Publik. Jurnal Masyarakat Telematika dan Informasi, Vol. 5 No. 1, Juni. ISSN 2087-3123.
Kovach, Bill dan Tom Rosenstiel. (2006). Sembilan Elemen Jurnalisme. Jakarta: Yayasan Pantau

Manan, Bagir (2012). Politik Publik Pers, Jakarta: Dewan Pers

Masduki, Darmanto, Muzayin Nazarudin, Budhi Hermanto, Anugrah Pambudi W., Sulistiyawati, Widodo Iman Kurniadi. (2013). Pemilu 2014 dan Konglomerasi Media NasionaI (Analisis terhadap Kecenderungan Pemberitaan 4 Group Media Nasional di Indonesia), JakartaYogyakarta: Dewan Pers - MPM (Laporan Penelitian).

McQuail, Denis. (2011). Teori Komunikasi Massa (Buku 1, edisi 6, terjemahan: Putri Iva Izzati). Jakarta: Penerbit Salemba Humanika.

Nugroho, Riant. (2013). Metode Penelitian Kebijakan. Yogyakarta: Pustaka Pelajar

Sani, Fitria Herawati, dan Yasnita Yasin (2014). Independensi Media Televisi dalam Memuat Berita Politik. Jurnal PPKN UNJ Online, 2 (4), 337 - 5205. Alamat Laman: http://skripsippknunj.org

Siregar, Amir Effendi. (2013). Independensi dan Netralitas Jurnalisme dan Media.Jakarta.,SKH Kompas, Sabtu, 20 Juli. Siregar, Amir Effendi. 2012. Menegakkan Demokrasi Penyiaran: Mencegah Konsentrasi, Membangun Keanekaragaman. Jakarta: Komunitas Pejaten

Siregar, Amir Effendi; Rahayu; Puji Rianto; Wisnu Martha Adiputra, 2014."Menakar Independensi dan Netralitas Jurnalisme dan Media di Indonesia" dalam Jurnal Dewan Pers Edisi No. 09, Juli, hal.3-39. Jakarta: Dewan Pers. ISSN: 20856199 
Darmanto, Urgensi Perubahan Kebijakan untuk Penegakkan Independensi Media di Indonesia

Tim Peneliti dari Masyarakat Peduli Media (MPM), 2014. "Pemilu 2014 dan Konglomerasi Media Nasional Analisis terhadap Kecenderungan Pemberitaan 4 Grup Media Nasional di Indonesia," dalam Jurnal Dewan Pers Edisi No. 09, Juli, hal. 43-85. Jakarta: Dewan Pers. ISSN: 20856199.

Wahyudin, Aep. (2014). Gurita Konglomerasi Politik Media Penyiaran di Kampanye Pemilihan Presiden 2014. Jurnal Observasi Vol. 12 No.2, hal. 113-128, ISSN:14125900, Bandung: BPPKI

Wibawa, Samudra. (2011). Politik Perumusan Kebijakan Publik. Yogyakarta: Graha Ilmu

Wicaksono, Anugrah Pambudi, Bonaventura Satya Bharata, Darmanto, Fajar Junaedi, Masduki, Olivia Lewi Pramesti, dan Puji Rianto. (2015). Media Terpenjara: Bayang-bayang Pemilik dalam Pemberitaan Pemilu 2014. Jakarta-Yogyakarta: Yayasan Tifa dan MPM

Widiyanto. (2009). Geger di Sisminbakum Sunyi di RCTI dan Okezone dalam Wajah Retak Media: Kumpulan Laporan Penelusuran, Jakarta Pusat: AJI Indonesia.

Winarno, Budi. (2014). Kebijakan Publik: Teori, Proses, dan Studi Kasus (cetakan kedua). Jakarta: CAPS
Peraturan Perundangan:

Undang-undang Nomor 40 Tahun 1999 tentang Pers

Undang-undang Nomor 32 Tahun 2002 tentang Penyiaran

PP. Nomor 11 Tahun 2005 tentang Lembaga Penyiaran Publik

PP.Nomor 12 Tahun 2005 tentang Lembaga Penyiaran Publik Radio Republik Indonesia

PP.Nomor 13 Tahun 2005 tentang Lembaga Penyiaran Publik Televisi Republik Indonesia

PP.Nomor 49 Tahun 2005 tentang Pedoman Kegiatan Peliputan Lembaga Penyiaran Asing

PP.Nomor 50 Tahun 2005 tentang Penyelenggaraan Penyiaran Lembaga Penyiaran Swasta

PP.Nomor 51 Tahun 2005 tentang Penyelenggaraan Penyiaran Lembaga Penyiaran Komunitas

PP.Nomor 52 Tahun 2005 tentang Penyelenggaran Penyiaran Lembaga Penyiaran Berlangganan

Surat Keputusan Dewan Pers No.03/SKDP/III/2006 tanggal 24 Maret 2006 tentang Kode Etik Jurnalistik (KEJ)

Peraturan KPI N0. 01/P/KPI/03/2012 tentang Pedoman Perilaku Penyiaran

Peraturan KPI N0. 02/P/KPI/03/2012 tentang Standar Program Siaran. 